ISSN 2520-6702 Міжнародний науковий журнал «Університети і лідерство» 1 (11), 2021

International Scientific Journal of Universities and Leadership

https://doi.org/10.31874/2520-6702-2021-11-1-35-44

UDC 378.013-047.22

Olaiya, Olajumoke Olufunmilola

\title{
A Discourse on the Contemporary Relevance of the Educational Underpinning of Plato's Political Philosophy
}

\begin{abstract}
The journey towards social ordering and the need to make life much better than it used to be is one of the principal motivations for political philosophy. Hence, there are as much political theories to this effect as there are political philosophers and scientists. Whereas the aim of the present research is to consider what kind of political theory can assist in social ordering, it does this, taking cognizance of the pedagogical postulates of the political scholar, Plato. In other words, this research reconsiders the educational underpinning of Plato's political philosophy for use in the quest toward the agenda of attaining nationhood in Nigeria. This comes as a consequence of the urgency to correct the ugly trend(s) that have greeted the educational system of the country as well as the failure of the social sciences to provide the much sought succor. This approach is sacrosanct because of the undue but accentuated emphases that have been given to the social sciences as the domain from which development and nationhood can spring. Incidentally, the journey toward nationhood for Nigeria, continues to be one of the most disturbing dilemmas that continues to haunt the country. Via the method of critical analysis, this essay argues that Plato's political philosophy has some educational ideals that present implications for contemporaneous nature or character of contemporary Nigeria. By giving emphasis on his reflections on the principle of specialization, this study is able to argue that the spirited application of this ideal for contemporary Nigeria via pedagogy will go a long way to birth the much sought nationhood. Political philosophy needs pedagogy to be able to realize its ideals. Unless this initiative is underscored, this essay submits, the quest for nationhood will continue to lament in the labyrinth of folly and backwardness.

Keywords: Education, Nationhood, Nigeria, Plato, Social Sciences.

\section{Introduction}

The political philosophy of Plato which is founded on his philosophy of education will be used as a mould to cater for the quest toward nation-building. Before engaging with the thrust of this work, it is important to state from the outset that a philosopher is usually confronted by some stark realities which may then account for their reflections as a way of overcoming. This is in line with the ideas of Emmanuel Ofuasia (2019) that there needs to be a blend of Western and non-Western episteme for advancements to be realized in several spheres of Africa's drive for economic liberation via pedagogy. This is the case of Plato who moved from the pedagogy of a would-be leader to analyse the ideal state. This study will employ such an itinerary owing to the reality of pseudo-development that has now become characteristic of African states as a groundwork. Excluding the introduction and conclusion, this work has five sections. The role of the philosopher king is succinctly articulated and examined in
\end{abstract}


the first section. In the second, the concept of Ideal State is given attention. The third concerns the meaning and nature of nation building. In the fourth, Plato's socio political ideas are examined, and in the fifth and final part, this study considers good governance as a means of democratic consolidation.

\section{Philosophy of Education in the Thoughts of Plato}

A good place to begin with Plato's political philosophy is the emphasis on who should govern the society, and this is why one of the most difficult and perplexing questions in political philosophy is «Who should rule?» a large amount of classical theories have dealt with it, and almost all of them can be classified according to how they attempt to answer it. If one holds that the people should rule themselves, he is advancing the democracy of (John Locke); if one holds that one man should, he may be a monarchist (Thomas Hobbes); and so forth. For Plato, this is the crucial question that every society must face, and his entire political philosophy can be understood as an attempt to answer it. Roughly, the Platonic answer is that a specially trained group of intellectuals should rule. Plato himself called his view «aristocratic». This was because he believed that intellectuals were best fitted to rule; indeed the Greek words ariston and kratos together mean «the rule by the best» (Popkin, Stroll, 1993: 60-1).

Plato talked about a philosopher King. Here, he emphasized the art of giving leadership role to the wise one otherwise referred to as 'philosopher King'. In his words:

Until philosophers are Kings, or the kings and princes of this world have the spirit and power of philosophy, and political greatness and wisdom meet in one, and those commoner natures who pursue either to the exclusion of the other are compelled to stand aside, cities will never have rest from their evils-on, nor the human race, as I believe, -and then only will this our state have a possibility of life and behold the light of day (Plato, 1968: 415).

He contended that the art of leadership role should be given to the philosopher King who had undergone Thirty five years of training or education in order to be fully and thoroughly equipped with knowledge and understanding of carrying the people along. However, it is pertinent to see how such ideas can be of great use in a situation where mass illiteracy and ad governance is the order of the day (Oyekan, Ofuasia, 2017). By his projection, the philosopher King should be that which had the community at heart that is, he should be statesman rather than a demagogue whose interest is his own welfare alone at the very expense of his people (the citizen of the state). For Plato, it seems natural that competence should be the peculiar abilities to fulfill that function. Disorder in the state is caused by the same circumstances that produce disorder in the individual, namely, the attempt on the part of the lower elements to usurp the role of the higher faculties.

Plato's idea of the philosopher king as the best man to rule the society, implies that leaders are made, and that a high level of intelligence and knowledge that is required for a leader in a society and state. It is often said that «knowledge is power». In order to see why the question «Who rule?» was of fundamental concern to Plato, it would be fruitful to refer to the social conditions that prevailed Greece at that time. The Political system in Nigeria is beset with lot of those even though they have certificates, but are not trained to be leaders of government. To achieve good governance, the one who govern should be above board.

According to Plato, politics is a science that should be left to the experts no less than with any craft, skill, or science. To elaborate on one of Plato's medical analogies, if you wanted to know whether 
you needed open-heart surgery; you would not put it to a democratic vote among your friends, your banker; or your automobile mechanic. Instead, you would seek the wisdom of physicians who are experts on this matter. Similarly, when it comes to formulating the policies and laws that govern the state, the democratic majority represents those least likely to make an informed decision. If we are concerned with the health of the body we yield to the advice of the experts. So, when we are concerned with the health of the state, we should similarly seek out those who have the necessary wisdom to govern. These experts must have vision of the Good. They must know what constitutes true knowledge. Just as a navigator must understand the stars and be able to use them to guide a ship through the vast ocean, so our political rulers must be able to navigate the ship of state by means of a vision of the Forms and the Good. Who else would these political navigators be but those with philosophical wisdom? (Lawhead, 2002: 61)

Plato's political ideas were informed by the anomalies of his time in the Greek City state of Athens. He resorted to solve or remedy the political problems of his time. At his time, there existed too, prolong and protracted wars as well as intensified civil strives throughout Greece. Plato's aim was to reform and then build a just society for Greeks. He felt there were lapses in the administration of the country (Greece, Sparta and others) during his period. In other words, the characteristic feature of the early rulers of Plato's time includes among others these: Egocentricism, Greediness, Nepotism and Favoritism. In other words, meritocracy had no place in the distribution of political portfolios. This resulted in the placement of mediocre in the helm of affairs instead of experts (Iroegbu, Izibili, 2004: 81). These features are in no small way, responsible for the backward state of affairs in terms of development. They are still found among most developing nations of the world today and this has been one of the catalogues of reasons responsible for their under- development (Eneanya, 1980: 321).

Plato was indeed worried about these deplorable conditions of the Greek City States of his time most importantly, the features aimed at postulating his ideal state which, was principally proposed that might confront the modern states social, political structures and ethical consciousness. In other words, it was Plato's intention to provide a blue- print for modern state to follow in order that they might not be overwhelmed by the same problems that the early Greek City States had to contend with, hence, his speculation on the word ideal.

Ideal state as opined by Plato, has to do with government versus citizen inter-relations that has the capacity of bringing about meaningful condition favorable for human growth and overall societal development. It was his firm belief that when the inherent factors that calls for meaningful development comes in, practical development cannot be talked about when the factors are lacking that is, when social political conditions that call for development are at a deplorable state. On the basis of this therefore, when we talk of an ideal state, we are expected to make a very conscious effort to build upon a social relations in order that in turn bring about political development (Iroegbu, Izibili, 2004: 81).

\section{The Essence of Nation-building}

The concept of nation building is another way to address national development. It is true that this has been variously viewed in dimension. Hence, there cannot be a one-sentence definition of national development. 
As earlier mentioned, the concept of nation building is another way to address national development and it has been variously viewed in dimension. Some see the work as consisting mainly of technological development and the setting up of all kinds of modern structures, accumulating an almost inexhaustible supply of the most sophisticated and deadly weapons. The ability to define the frontiers of a nation a high percentage of mass literacy control of buoyant economy, and in short, being in possession of all kind of material goods, which are calculated, to make man's life happy and also guarantee national security by force of arms, is yet another view of nation building (Omeregbe, 1990: 194).

The building of a nation such as we envisage, cannot be achieved by the mere accumulation of material things or the procurement of a life of comfort and ease often to a limited few. This alone will not make man really happy for the simple reason that man is not mere matter. He is a composite of matter and spirit and he has destiny for beyond the confines of this world. He has an eternal destiny. In the light of the above, any project for the building of a nation, which loses sight of, or ignore the spiritual and material cannot achieve its goal. Well-being of man taken as a whole cannot succeed in building a nation in which no man is oppressed. Therefore, the work of nation building has both the material and the spiritual aspects. Nation building calls for the builders who are morally conscious. This said, morality should flow naturally from religious creed. This will further bring about patriotism. The love and loyal zealous support of one's own country, especially in all moral foundation, in piety, and social basis in the community (Iroegbu, Izibili, 2004: 81).

It is however noteworthy, that it takes a well-built people to build a nation that is virile and strong. Perhaps this is why Plato advocated that the emergence of a philosopher-king through rigorous but step-by-step quest for knowledge that will distinguish those who takes the leadership position from that of the craftsmen and solders. For a better understanding of this, it is necessary to discuss Plato's social and political ideas.

Plato's Philosophy of Education and the Drive for Nation-Building: The Nigerian Example

In his conception of an ideal state, Plato believed that man is not self-sufficient and therefore without the state, man cannot be self-fulfilled. On the basis of this, he threw light on human development as an integral part of the societal development and verse-versa. As a man is important in the creation and development of the society, so also is the society very important to the development of man. Hence, without the state, man cannot be self-actualized. Man, like we know, needs to be aided in his quest for self-actualization and this has to do with the availability of the potentialities made realizable within the limit of the state, resource (Iroegbu, Izibili, 2004: 83).

Before understanding and appreciating the relevance of Plato's philosophy of education in the quest toward nation-building in Nigeria, it is pertinent to have a terse glimpse into some of the $21^{\text {st }}$ century realities of the country's educational system.

It is instructive to begin with the ultimate character of Nigeria's educational system in recent times. One of the major problems that beset Nigeria today is the issue of unemployment. Many graduates of higher institutions of learning hopelessly carry their curriculum vitae from one company to another for years in search of jobs. This frustrating situation has led many Nigerian graduates to be involved in so many vices. Statistics reveal that unemployment in Nigeria increased from 21.1 percent 
in 2010 to 23.9 percent in 2011 with youth unemployment at 50 percent. From 2011 to 2013, there is an increase of 16 percent unemployment rate in Nigeria (Uddin, Uddin, 2013). In fact, the recent illfated recruitment exercise by the Nigerian Immigration Service (NIS) where no fewer than 5000 youths turned up for recruitment exercise to fill vacancies of less than 1 percent of their population (that is, less than 5,000 vacancies) in the service (Abiola, 2014).

The Nigerian system of education is more of a certificate-based education in both structure and functionality than a competence-based one. It emphasizes «paper qualifications» over knowledge, skills, and technical know-how. Often times, the emphasis is on how well one passes an exams and not how well one knows a particular discipline, so most students cram just to pass an examination only to forget after the exams. Such students end up making good grades and earn wonderful certificates but are actually bereft of any knowledge necessary for a gainful employment in the future. There are also other students who go to the extent of cheating in an examination because they are merely after good grades and not the kind of knowledge that offers them the authority of competence (Irikefe, 2013). So, the labour market is flooded with graduates who lack the authority of competence are and are equally clueless in creating jobs for themselves.

This is not calculated to condemn certificates. The point however, as Actoria (2012) claims is that certificate-based education has lost relevant in recent times. According to Roselin (2012), the duty of education is to develop in students the Strategic ability to deal with practical issues of their day-today experiences within and outside their environment. That is to say, the learning process must be societal based as well as a means of bringing the world and the needs of the labour market into the classroom. Thus, the students should be taught how to develop inventive skills, problem solving oriented attitude, and self-developmental skills. The fact is that, as Obemeate (1990) observes, education is much more comprehensive than the mere process of learning to read and write, acquiring certificates in one field of specialization or another. It goes much deeper; it is concerned with the growth of habits and lifestyle that makes a man what he is. Nigeria is blessed with many higher institutions of learning. But the low standard of education jeopardizes most graduate's chances of job security since they do not possess the adequate skill needed for the job and also, many employers are skeptical about the applicability of their intelligence in the work place (Eseola, 2016).

In the first instance, Plato's social ideas in The Republic invite a social relation, which implies a common ownership of property among the guardians and the auxiliaries. The abundance of love, peace and harmony noticeable in a communalistic organization is in fact an ideal structure of human existence. This makes it possible for people to live as the same ancestral family without the ideology of inequality and class differences, which create disaffection among members of the same community (Bogomolove, 1985: 189). This said, communal existence as advocated by Plato does not create room for capitalistic exploitation, class distinction, divided minds, inevitable class struggles, which would result from the awareness of suppression and subjugation and element of repression of the less privileged ones. The fact that there is no class distinction among the people would make them adhere to one and the same ideology; i.e. there would be no room for ideological differences as found in most modern states today. No doubt, these various elements of a communalistic society are a fundamental ingredient for national development. 
Plato made plain, the relationship between the individual and the state. His whole argument was that individual and the state. His whole argument was that the state grows out of the nature of the individual, so that logically, the individual comes prior to the state. The state, said Plato, is a natural institution, natural because it reflects the structure of human nature, the origin of the state is a reflection of man's economic needs. In his words, a state comes into existence because no individual is self- sufficing; we all have many needs (Plato, 1968: 415).

Our many needs require many skills, and no one possesses all the skills needed to produce food, shelter and clothing, to say nothing of the various arts. As Plato (1968: 415) also expatiates:

There must, therefore, be a division of labour for more things will be produced and the work more easily and better done, when every man is set free from all other occupations to do, at the right time, that one thing for which he is naturally filled.

Hence, a social relation of symbiotic, sort of, becomes the product of the forming of a government by man. This simple but important idea stresses widely to a complex nature in showing the ideal social relation, which would exist between the rulers and their subject in the state.

Man's needs are not limited to his physical requirements for his good is not simply survival but a life higher than that of animals. The government is necessarily obligated to provide the essentials of life to its citizens and to protect their integrity and dignity. The citizens have their own side of the bargain to keep and that is that of the state that is stipulated in its code of conduct. Parts of these expectations include: payments of taxes and rates promptly. A detail of this and others are found in Plato's Republic which was handed down by Plato as a blue print of an ideal state. This is analogous to the principles and policies, which would be used or applied to nation policies for it to rise to the threshold of development.

In his socialization crusade, he advocated for «the children of the rulers and soldiers to be children of the state; akin to totalitarian doctrine. Since the children of the rulers and soldiers should be under the care of the state rather than the state allowing rulers and soldiers to take care of their children themselves, seems to create effectiveness in the ruler's administration of the state. This in addition, will lead to more efficiency on the part of the solders in the discharge of their duties to the state, than it would have been when they are made to face with both family life responsibilities and that of the state duties.

Plato's Socio-political ideas could in no small way aid nation building if properly appropriated. Take for example his opinion on the spirit of statesmanship. A community where such exists would never be short of development because the statesman has the interest of the community at heart rather than his own selfish interests as seen in most parts of modern day government of the world especially African and the so- called third world nations. He advocated for public ownership of property and children to enhance the efficiency of the ruler in the discharge of his duties to the state and inert the emergence of self-interest, which would lead to embezzlement of public funds.

Moreover, Plato's political idea in nation building expressly elucidated the nature of man. Man, he said, is made by God and has been placed in a community where he gets what he wants and actualizes his dreams and aspirations. Hence, we cannot talk of development of man without reference to the state. This is because Plato considered the state as being «Man Writ large» (Plato, 1968: 415). But Plato did not simply say that there is an interesting or coincidental connection between the just 
man and the society. He argues, rather, that there is a structural and natural as well as logical relation between man and the state. Put differently, the state must have to exist for man to live and survive within the available provision of the state. That is the existence of man, necessitates the existence of the state; if this is true, therefore, the development of man within the state he lives in equally corresponds to the development of the state itself.

Plato emphasized a social relation, which stipulates the ideal years or age, which a man and woman may attain before being married, it is in his view that a man should undergo a prolong training to about the age of thirty five to forty five years, within which he may have been wisely endowed before getting married. The same thing, he recommended for the female that is, that a lady should attain the age of twenty five to thirty years before getting married. Within this age bracket, she must have been educated as her male counterpart. The advantage of this among others is that it makes way for a nation to have a thoroughly equipped work force, which in no small measure contributes to the development of the nation in all spheres (economically, socially and above all, morally) (Stumpf, 1993: 138). He warned against immoral teaching of such doctrines that would pollute the young minds and make them to be social deviants. These vices, to say the least would not move a nation forward. It would rather constitute a stumbling block when one considers the restive nature of most youths then and now.

It is instructive to begin with the idea that when the Nigerian education system is given adequate attention, when fairness, equity and merit are upheld over nepotism, disequilibrium and docility, Plato's 'Principle of Specialisation' may then be brought to bear. Children from the period they enter into school are given special attention. While it is clear that not every child will be in love with books, they must be allowed to develop their instincts in so far as they are not harmful to self and others. It is likely that when these instincts are developed, they become skills which may be horned to bring about the best in the individual for social utility.

There will be separation as Plato recommends in his pedagogy. Those who are very brilliant will be encouraged to read on and specialize in whatever branch of knowledge that they aspire. They will be the policy makers and administrators of the state, what Plato will call guardians. Among these there will be those that will be individuals that are bred for social progress and development. They will not be affiliated to tribe and religion. Their primary agenda is to steer the ship of the state toward the principle of freedom, equity and dignity. It is a combination of these trios that development may then emerge.

Consequently, it is among these highest breed of society that the Executive, Legislative, and Judiciary arms of government will emerge, just like Plato's division of artisans, auxiliaries and soldiers. Recall that Plato emphasizes that there need not be connection or interference among these three, an outlook to be made more eloquent by Baron de Montesquieu. Hence, during elections, there is a particular class in society where leaders who had been bred by the state will emerge from. Those that will occupy the positions of the Executive and Legislature will be individuals like anybody that has gone through the rigorous training that leads them to this position. It will be inappropriate to vote someone from the Judiciary into a seat in the executive or legislature for that matter. The kind of education and preparation for that sensitive position has not been horned in this individual. 
It is the position here that when children are nurtured and given due attention, corrupt individuals who see politics as a means to an end will no longer proliferate (Abanum, 2015). Democracy will be practiced with the hindsight of good governance and the rewards will be all to plain to see since it's no longer about who occupied a juicy position and who doesn't. It will be about the best candidate who has endured decades of training for the position. Democratic governance will be a way of merging practice with theory by these trained minds.

\section{Conclusion}

Plato's social political thought as carefully adumbrated in this paper, had a far reaching effect on nation building when a nation applies them to it is national policies, though it had been observed in most quarters that his ideal state is not realizable. For this all important reason, nations should endeavor to appropriate it is an approximation to national policies most especially the so-called third world nations that have been plagued with this colossal problem. This idea could help in nation building though its concept of «The good and Justice». The idea of good ruler in his ideal state was made plain on his notion of philosopher-king. To him, those who have undergone a special kind of training must rule to have an ideal state and they must be philosopher- kings. They are to be trained in philosophy and mathematical ideas, which leads to abstract contemplation of reality. The concept of justice as spelt out in Plato's ideal state is a complementary principle of differentiation, keeping the various parts distinct with each part minding its function without the various parts encroaching on one another's or usurping their functions, while injustice is a deliberate encroachment on the function of the other which will lead to a disharmony in the state. There would be national development if nations could appropriate Plato's ideas. Though an ideal state as advocated by Plato may not be realizable in our contemporary world, it must be noted however, that a state is capable of getting close to being ideal if individuals within a given society have the interest of that society at heart by shunning such vices as greed, over ambition, jealousy, hatred, racial and tribal sentiments and the likes, and when virtues such as self-contentment and the likes are embraced by leaders and the subjects alike, nations in the world most especially third world countries result gradually draw close to what an ideal state should be. It must be noted however, that achieving the ideal is a continuous process that must be sustained. Plato's theory of the state, though not realizable, is a good antidote for a bad government. Though it has some demerits as all political systems must have, Plato beautifies his theory of state that could be referred to as ideal. Many modern states can still learn from his system.

\section{References}

Abanum, S.C. (2015). «Salvaging Local Industries: A Call to National Development» in "The Sage Magazine», vol. 28, February 2015-2016.

Abiola, S. (2014). «Nigeria's Educational System and its Unemployable Gradates». In Daily Post: Nigeria

Online Newspaper, April 21. http://dailypost.ng/2014/04/21/abiola-solanke-nigeriaseducational-system-unemployable Last accessed on September 10, 2020.

Actoria, H. (2012). Academic Life and Social Change. London: Noble books

Bogomolov, A.S. (1985). History of Ancient Philosophy. Moscow: Progress Publishers. 
Eneanya, S.N. (1980). The Contribution of African Traditional Religion to Nation Building. Social Sciences: Issues in National Development, Edited by E. C. Amucheazi. Enugu: Fourth Dimension Publisher.

Eseola, E. (2016). «The Challenges of Unemployment in Nigeria vis-à-vis the Future of the Nigerian Youth». The Sage Magazine. 28, February.

Irikefe, P.O. (2013). Why Nigeria is Not Working: The Predicament and the Promise, Ibadan: Kraft Books.

Iroegbu, P.O., \& Izibili, M.A. (2004). Kpim of Democracy Thematic Introduction to Socio-Political Philosophy. Benin City: Ever-Blessed Publishers.

Lawhead, W.F. (2002). The Voyage of Discovery: A Historical Introduction to Philosophy. Belmont: Wordsworth.

Obemeate, J.O. (1990). The Catholic Church on Education. Ibadan: Wisdom Publishers Ltd.

Ofuasia, E. (2019). John Dewey's and Julius Nyerere's Views on Education and the Implication of their Ideas for African Development. Philosophy of Education, 25(2),. 127-141. https://doi.org/10.31874/2309-1606-2019-25-2-7

Omoregbe, J.I. (1990). Knowing Philosophy. Lagos: JOJA Educational and Research Pub. Ltd.

Oyekan, A.O., \& Ofuasia, E. (2017). A Rawlsian Reflection on Ideology, Violence and Extremism in Postcolonial Africa. UNILAG Journal of Politics, IX (2), 19-37.

Plato. (1968). Republic. B. Jowett. (Trans.). New York: Airmount Publishing Co. Inc.

Popkin, R.H., \& Stroll, A. (1993). Philosophy Made Simple. New York: Broadway Books.

Roselin, P., (2012). Examination Malpractice and Integrity of Educational Credentials. Canada: Unpublished lectures on Certificate Education, 4th Edition.

Uddin, P.S.O., \& Uddin, O.O. (2013). Causes, Effects and Solutions to Youth Unemployment Problems in Nigeria. Journal of Emerging Trends in Economics and Management Services, 4.

Olaiya, Olajumoke Olufunmilola

\section{Дискурс о современной актуальности образовательной основы политической философии Платона}

\section{Анотація}

Шлях до соціального впорядкування та необхідність зробити життя набагато кращим, ніж було раніше, є однією з головних мотивацій політичної філософії. Отже, існує стільки політичних теорій на цей рахунок, скільки політичних філософів та вчених. Хоча метою цього дослідження $\epsilon$ розглянути, який вид політичної теорії може допомогти у соціальному впорядкуванні, ми робимо це, беручи до уваги педагогічні постулати політолога Платона. Іншими словами, це дослідження переглядає освітню основу політичної філософії Платона для використання у пошуках порядку денного досягнення державності в Нігерії. Це відбувається як наслідок терміновості виправлення потворних тенденцій, які охопили освітню систему країни, а також неспроможності соціальних наук надати бажану допомогу. Цей підхід $€$ недоторканним через невиправдані, але підкреслені акценти, які були надані соціальним наукам як галузі, з якої може випливати розвиток та 
державність. До речі, шлях Нігерії до державності залишається однією з найбільш тривожних дилем, яка продовжує переслідувати країну. За допомогою методу критичного аналізу дана робота стверджує, що у політичній філософії Платона містяться деякі освітні ідеали, що в той же час становлять собою значні висновки і для сучасної Нігерії. Наголошуючи на його роздумах про принцип спеціалізації, це дослідження може стверджувати, що енергійне застосування цього ідеалу для сучасної Нігерії за допомогою педагогіки матиме велике значення для народження такої бажаної державності. Політичній філософії потрібна педагогіка, щоб мати можливість реалізувати свої ідеали. Якщо ця ініціатива не буде підкреслена, стверджується в цьому есе, прагнення до державності продовжуватиме плакати в лабіринті глупоти та відсталості.

Ключові слова: освіта, національність, Нігерія, Платон, соціальні науки.

Інформація про автора:

OLAIYA, OLAJUMOKE OLUFUNMILOLA

- Lecturer

- $\quad$ Nigeria

- Department of Educational Foundation, Federal College of Education, Akoka.

- $\quad$ E-mail: olaiya.olajumoke@yahoo.com 